\title{
ECONOMIC AND MATHEMATICAL MODELING OF THE INTEGRATION IMPACT OF MODERNIZATION ON INCREASING THE ENTERPRISE COMPETITIVENESS
}

\author{
Olha Vovk ${ }^{1}$, Svitlana Tulchynska ${ }^{2}$, Olha Popelo ${ }^{3}$, Rostislav Tulchinskiy ${ }^{4}$, Tetiana Tkachenko ${ }^{5}$ \\ ${ }^{1}$ Doctor of Economic Sciences, Associate Professor, Associate Professor of the Department of Air Transport \\ Economics, National Aviation University, Lubomyr Husar Avenue, 1, Kyiv, 03058. \\ E-mail address: economy.nau@gmail.com \\ ${ }^{2}$ Doctor of Economic Sciences, Professor, Professor of the Department of Economics and Entrepreneurship, National \\ Technical University of Ukraine "Igor Sikorsky Kyiv Polytechnic Institute", 37 Prosp. Peremohy, Kyiv, 03056, \\ Ukraine. E-mail address: tuha@ukr.net
}

${ }^{3}$ Doctor of Economic Sciences, Associate Professor, Associate Professor of the Department of Management and Civil Service, Chernihiv Polytechnic National University, Ukraine, 95 Shevchenko Str., Chernihiv, 14035, Ukraine.

E-mail address: popelo.olha@gmail.com

${ }^{4}$ Doctor of Economic Sciences, Associate Professor, Head of the Department of Management and Public Administration, IHE "Academician Yuriy Bugay International Scientific and Technical University", 3 lane Magnitogorsky, Kyiv, 02000, Ukraine. E-mail address: r_istu@ukr.net

${ }^{5}$ Associate professor of the Department of economics and entrepreneurship of the Faculty of Management and Marketing Igor Sikorsky Kyiv Polytechnic Institute, 37 Prosp. Peremohy, Kyiv, 03056, Ukraine.

E-mail address: tatvla@ukr.net

Received 0308 2021; Accepted 05082021

\begin{abstract}
Within the article, the economic model of the integration impact of modernization on the enterprise competitiveness and ensuring its economic security is described and substantiated. The authors formalize the factors and patterns of increasing a competitive advantage under the influence of the modernization potential implementation. It is determined that to ensure the competitiveness and economic security of the enterprise it is necessary to carry it out in compliance with the conditions of complexity of strategic reforms, clarity of modernization tasks, speed of adaptation of the modernization process to external environment, coherence of reform levels. Assessment and strategic analysis of competitiveness according to the "3S" model of Ukrainian infrastructure enterprises revealed the dependence of the effectiveness of modernization on the existing institutional and market environment, the level of staff competence, the dynamism of innovation and investment support.
\end{abstract}

Keywords: competitiveness, integration influence, speed of implementation, stability of innovations, space of modernization, $3 S$ model, cognitive analysis, enterprises.

JEL Codes: O1, O2, O4.

\section{Introduction}

Modern conditions of the enterprise formation create new challenges and stochastic models of the market behavior. If until recently it was considered acceptable to operate the company on the principles of the

\begin{abstract}
self-renewal system (which should happen through the mechanisms of profitability and depreciation of assets, appropriate socio-economic reproduction of staff, etc.), today in the conditions of the
\end{abstract}

Copyright ( 2021 Author(s), published by Vytautas Magnus University. This is an open access article distributed under the terms of the Creative Commons Attribution Non-Commercial 4.0 (CC BY-NC 4.0) license, which permits unrestricted use, distribution, and reproduction in any medium provided the original author and source are credited. The material cannot be used for commercial purposes. 
dynamics of market relations and the emergence of new competitive technologies, products or services, enterprises have reduced competitiveness, they show loss of ability to self-reproduction due to reduced resource efficiency and economic security.

The solution to the described problems lies in the plane of accelerating the enterprises modernization, increasing the competitiveness of enterprises and ensuring their economic security through the formation under its influence of new competitive advantages.

\section{Literature review}

Scientific researches of domestic and foreign scientists are devoted to the issues of efficient implementation of the enterprise potential modern competitive conditions, among which: Aleksandrov I., Rasskazova O. (2020); Azhaman I., Zhydkov O., (2020); Belyakov G., Belyakov S. (2020); Gonchar O., Khachatrian V. (2020); Graf P., Rowland Z. (2020); Khanin S., Derhaliuk M. (2021); Kleshchov A., Terentiev O. (2020); Korepanov G., Yatskevych I. (2020); Krawczyk-Sokolowska I., Pierscieniak A. (2021); Rementsov A., Lebedeva N. (2021); Samiilenko H., Khudolei V. (2021); Samoilovych A., Garafonova O. (2021); Sytnyk H., Vysochyn I. (2021); Sychev M., Evstafieva A. (2020) et al.

In the article (Gonchar et al., 2020), features of financial activity and economic security of modern enterprises in an unstable environment are considered. The purpose of the article (Graf et al., 2020) is to assess potential of the small business valuation using the FCFF discount methodology based on the example. Practical application of the research method is demonstrated in an example that focuses on a specific but randomly selected enterprise. The aim of the work (KrawczykSokolowska et al., 2021) is to identify the factors of innovation potential at Polish enterprises, which are key in terms of the enterprise innovation and their impact on economy.
Within the study (Azhaman et al., 2020), the formation of economic potential of the enterprise, as exemplified by service enterprises for repair and maintenance of vehicles, is considered. The authors (Aleksandrov et al., 2020) propose an approach to quantifying potential and intellectual capital of agro-industrial companies. Quantitative assessment of economic potential will provide an opportunity to evaluate intellectual capital of the company as a whole, as well as the components of intellectual capital. The results presented in the article (Belyakov et al., 2020) are aimed at taking into consideration the impact of the level of scientific and technical development of the state on the foreign trade potential of machine-building enterprises.

In the article (Kleshchov et al., 2020), problematic issues of assessing potential and improving energy efficiency in mining enterprises are considered. The authors (Sychev et al., 2020) of the article argue that to assess the risks of using economic potential, it is divided into resource, production and financial. As a method of risk assessment, scientists have chosen a statistical method based on the calculation of the coefficient of variation. The study (Belyakova et al., 2020) is focused on the formation of a model of the information technology platform for the development of foreign trade potential among machine-building enterprises as a basis for technological development of machine-building enterprises, as well as on the study of tasks and main components of the information technology platform. The article (Rementsov et al., 2019) deals with some topical issues of effective management of the use and development of production potential of the enterprise. In the article (Korepanov et al., 2020) is stated that the assessment of the financial stability potential is one of the priority tasks of commercial diagnostics of crisis enterprises, the state of which is characterized by an increased probability of bankruptcy and tends to absolute insolvency. 


\section{Sciendo}

Management Theory and Studies for Rural Business and Infrastructure Development eISSN 2345-0355. 2021. Vol. 43. No. 3: 383-389

Article DOI: https://doi.org/10.15544/mts.2021.35

\section{Methodical approach}

Substantiating the integrated indicator of the modernization impact on the competitiveness of the enterprise, technologies of weight establishment and correlation of individual parameters were used. To prove the feasibility of using certain promoters, the authors analyzed the models of the cognitive analysis of expert judgments, ranking and concordance of parameters. This allowed to formalize economic and mathematical tools for analyzing the impact of modernization on the competitiveness of enterprise and ensuring its economic security.

\section{Results}

It is proposed to analyze possible factors formed under the influence of modernization, and the nature of their implementation in increasing competitiveness of the enterprise in the markets and ensuring their economic security by generalized integrated parameters: speed, stability and spaciousness (hereinafter "3S"):

$$
f(C)=\left(S_{p}, S_{t}, S_{n}\right)
$$

where, $f(C)$ - function of dependence of the competitiveness of the enterprise and maintenance of its economic safety;

$S_{p}-$ speed of the impact of modernization on increasing the competitiveness of the enterprise;

$S_{t}$ - increasing the stability of the competitive position of the enterprise in the market;

$S_{n}$ - scope of modernization of the existing competitive advantages.

Functional dependence of the competitiveness on the integrated parameters of modernization of infrastructure enterprises in the "3S" model is implemented through the transformation of technical or managerial innovations, introduced in the form of modernization, into competitive advantages, the accumulation of which forms the competitiveness of products, enterprises and economic security (Fig. 1).

Forming a complex indicator of integration impact, mathematical tools to compare the obtained estimated value with the reference / average / sectoral / target value, as well as the mechanism for determining the weighted arithmetic mean using the weight of all calculated indicators in the group of parameters are used. 
Olha Vovk, Svitlana Tulchynska, Olha Popelo, Rostislav Tulchinskiy, Tetiana Tkachenko

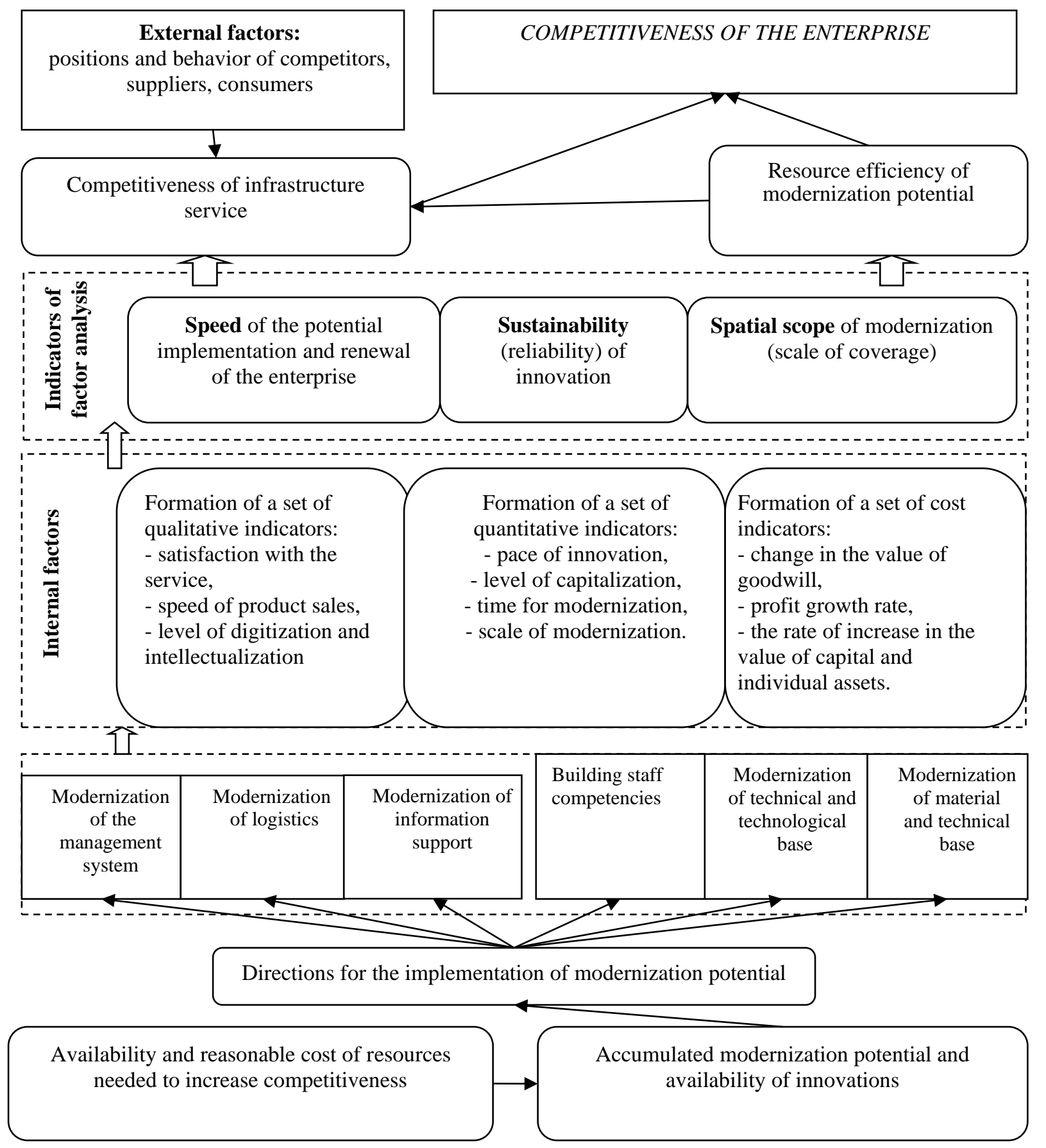

\section{Figure 1. "3S" model for integrated analysis of the factor impact of modernization of the competitiveness and economic security of the enterprise}

*Source: described by the authors

The sequence of formalization of the economic-mathematical model of the factor analysis of the integration impact of modernization of the competitiveness and economic security of the enterprise includes many step-by-step stages.

At the first stage of modeling the factor impact of modernization of the competitiveness and economic security of the enterprise, list of key indicators for each parameter will be formed.

The second stage of the model formalization is to establish the weight of indicators in the evaluation system (Table 1). At this stage, tools of cognitive judgment are 
used, and a number of requirements for the relevance of the results are met: within $0-1$;

- values of indicators are assigned

- the sum of estimates of indicators in one parameter must be equal to one $(100 \%)$;
- results of the evaluations must be consistent and reliable.

- the number of variations of estimates will be accepted according to the obtained results, setting a step for assigning values to 5 units.

\section{Table 1. Establishing the weight of indicators in the "3S" model using the tools of cognitive judgment, $\%$}

\begin{tabular}{|c|c|c|c|c|c|c|c|c|c|c|c|c|}
\hline \multirow[t]{2}{*}{ Indexes } & \multicolumn{11}{|c|}{ Cognitive judgments of experts } & \multirow{2}{*}{$\begin{array}{c}\text { Average } \\
\text { value }\end{array}$} \\
\hline & 1 & 2 & 3 & 4 & 5 & 6 & 7 & 8 & 9 & 10 & 11 & \\
\hline 1. Speed: & 25 & 25 & 20 & 30 & 20 & 20 & 25 & 30 & 20 & 35 & 20 & 23,6 \\
\hline 2. Stability: & 40 & 40 & 40 & 35 & 40 & 35 & 40 & 45 & 35 & 20 & 40 & 37,3 \\
\hline 3. Spatial: & 35 & 35 & 40 & 35 & 40 & 45 & 35 & 25 & 45 & 45 & 40 & 39,1 \\
\hline The total weight of the parameter, $h$. & 100 & 100 & 100 & 100 & 100 & 100 & 100 & 100 & 100 & 100 & 100 & \\
\hline
\end{tabular}

*Source: summarized by the authors on the basis of expert assessments

Thus, the calculations showed the acceptability of many selected indicators and their importance in the model, as well as the consistency of expert judgments. The consistency of cognitive research falls in the range of $1-0.4$, so we can reasonably say about economic feasibility and mathematical relevance of the proposed model.

The third stage of modeling the diagnostic process of the enterprise competitiveness under the modernization impact is to establish reference / average / sectoral / target values of selected indicators. Since all the proposed indicators for each parameter reflect relative dynamics of change, their growth as a positive assessment will be taken into account, and the reference value will be more than one.

In the fourth stage, we formalize the formulas for assessing the integrated impact. Applying the obtained weight parameters, the formula is described as follows:

$C=S_{p} * q_{p}+S_{t} * q_{t}+S_{n} * q_{n}=S_{p} * 0,236+S_{t} * 0,373+S_{n} * 0,391$

where $S_{p}$ - the parameter of the speed of the modernization impact on increasing competitiveness and ensuring economic security of the enterprise;

$q_{p}$ - the weight of the parameter of the rate of the modernization impact;

$S_{t}$ - the parameter of stability of a competitive position of the enterprise in the market;

$q_{t}$ - the weight of the stability parameter of the competitive position

$S_{n}$ - the parameter of spatial coverage by modernization of existing competitive advantages;

$q_{n}$ - weight of the spatial parameter.

Examining in more detail the level of competitiveness and economic security of infrastructure enterprises in terms of speed, stability and spaciousness of modernization using the "3S" model, we can say that the monopoly position in the markets of infrastructure services in some areas (JSC "Ukrzaliznytsia", SE "UkSATSE" ) whether the duopolism of the markets of postal and airport services (SE MA "Boryspil", SE "Ukrposhta") does not affect the overall results of the assessment (Table 2). 
Olha Vovk, Svitlana Tulchynska, Olha Popelo, Rostislav Tulchinskiy, Tetiana Tkachenko

Economic and Mathematical Modeling of the Integration Impact of Modernization on Increasing the Enterprise Competitiveness

Table 2. Assessing the impact of modernization on the competitiveness and economic security of infrastructure enterprises using the "3S" model

\begin{tabular}{|c|c|c|c|c|c|c|}
\hline \multirow{2}{*}{ Enterprises } & \multicolumn{5}{|c|}{ Analyzed period } & \multirow{2}{*}{$\begin{array}{c}\text { Dynamics of the } \\
\text { indicator change, } \\
2019 / 2015\end{array}$} \\
\hline & 2015 & 2016 & 2017 & 2018 & 2019 & \\
\hline \multicolumn{7}{|c|}{ JSC "Ukrzaliznytsia" } \\
\hline Level of competitiveness & 1,62 & 1,75 & 1,20 & 1,23 & 1,26 & 1,62 \\
\hline - speed factor & 0,48 & 0,59 & 0,06 & 0,05 & 0,07 & 0,48 \\
\hline - coefficient of stability & 0,219 & 0,249 & 0,279 & 0,314 & 0,335 & 0,219 \\
\hline - coefficient of spatiality & 0,93 & 0,91 & 0,86 & 0,87 & 0,85 & 0,93 \\
\hline \multicolumn{7}{|c|}{ JSC "Ukrposhta" } \\
\hline Level of competitiveness & 1,81 & 1,36 & 1,73 & 2,20 & 2,06 & 1,14 \\
\hline - speed factor & 0,42 & 0,21 & 0,54 & 0,41 & 0,55 & 1,29 \\
\hline - coefficient of stability & 0,927 & 0,423 & 0,694 & 1,119 & 0,998 & 1,08 \\
\hline - coefficient of spatiality & 0,46 & 0,73 & 0,49 & 0,67 & 0,52 & 1,13 \\
\hline \multicolumn{7}{|c|}{ DP "AMPU" } \\
\hline Level of competitiveness & 0,782 & 1,185 & 1,169 & 1,065 & 1,168 & 1,494 \\
\hline - speed factor & 0,212 & 0,204 & 0,179 & 0,104 & 0,091 & 0,430 \\
\hline - coefficient of stability & 0,330 & 0,353 & 0,355 & 0,291 & 0,317 & 0,962 \\
\hline - coefficient of spatiality & 0,24 & 0,628 & 0,636 & 0,670 & 0,760 & 3,165 \\
\hline \multicolumn{7}{|c|}{ UkSATSE } \\
\hline Level of competitiveness & 0,959 & 0,947 & 1,277 & 0,552 & 12,572 & 13,116 \\
\hline - speed factor & 0,351 & 0,398 & 0,379 & 0,051 & 0,771 & 2,195 \\
\hline - coefficient of stability & 0,077 & 0,076 & 0,474 & 0,005 & 5,929 & 76,688 \\
\hline - coefficient of spatiality & 0,530 & 0,473 & 0,424 & 0,497 & 5,872 & 11,080 \\
\hline \multicolumn{7}{|c|}{ SE "MA" Boryspil "'" } \\
\hline Level of competitiveness & 1,173 & 1,254 & 1,361 & 1,703 & 1,359 & 1,158 \\
\hline - speed factor & 0,143 & 0,169 & 0,154 & 0,206 & 0,129 & 0,901 \\
\hline - coefficient of stability & 0,279 & 0,367 & 0,432 & 0,534 & 0,273 & 0,980 \\
\hline - coefficient of spatiality & 0,752 & 0,718 & 0,775 & 0,963 & 0,957 & 1,273 \\
\hline
\end{tabular}

*Source: constructed by the authors based on the evaluation results

The results of the strategic analysis of competitiveness and economic security according to the " $3 \mathrm{~S} "$ model of each of the surveyed enterprises showed the dependence on the existing institutional and market environment, the level of staff competence, the dynamics of innovation and investment support.

\section{Conclusions}

The assessment of the modernization impact on the competitiveness and economic security of infrastructure enterprises allows to state the monopoly of certain transport sectors and shows the general picture of the dependence of the competitive position on the level of technology, innovation of service technologies, mobile or production facilities and infrastructure.

The application of the "3S" model will provide an opportunity for the company to determine the change in market position and competitiveness due to the modernization potential implementation. For infrastructure enterprises, especially international ones, the implementation of modernization potential is not just a way to ensure technical compliance with growing international standards, but a tool for integrated strategic management of development and profitability.

The calculations allow us to draw conclusions about the multi-vector and mandatory modernization process in the infrastructure sector of Ukraine. Considering the activities and market position of each enterprise in the context of ensuring the effectiveness of the modernization impact on competitiveness and development, we see a lack of motivation to activate existing resource opportunities and to use the monopoly position in the market of certain infrastructure services. 
Further research is required to develop a system for ensuring economic security of enterprises in a competitive environment in terms of the modernization of enterprise capital and its evaluation.

\section{References}

Aleksandrov, I., Rasskazova, O., Popazova, O., Petrov, M., Chekhovskikh, I. (2020). Economic potential of agroindustrial enterprises and their impact on the environment. E3S Web of Conferences, ERSME 2020, 20 October 2020 - 23 October 2020 (vol. 217, 09003). https://doi.org/10.1051/e3sconf/202021709003.

Azhaman, I.A., Zhydkov, O.I., Hronska, M.V., Petryshchenko, N.A., Serohina, N.V. (2020). Formation of economic potential of the enterprise (Service enterprises - Repair and maintenance of vehicles) evidence from Bosch Company. International Journal of Criminology and Sociology, 9, 2875-2881. DOI: https://doi.org/10.6000/19294409.2020.09.352.

Belyakov, G., Belyakov, S., Fokina, D., Shpak, A. (2020). Scientific \& technological development as the basis for increasing the foreign trade potential of engineering enterprises. Journal of Physics: Conference Series, 1679(325), 032034. doi:10.1088/1742-6596/1679/3/032034.

Belyakova, G., Belyakov, S., Fokina, D., Shpak, A. (2020). Formation of a model of the information technology platform for the development of foreign trade potential as the basis for technological development of engineering enterprises. IOP Conference Series: Materials Science and Engineering, 16 April 2020 - 18 April 2020 (vol. 862, is. 427, 042033). doi:10.1088/1757-899X/862/4/042033.

Gonchar, O., Khachatrian, V., Ostapchuk, O., Bitiy, A. (2020). Assessment of financial security in the enterprise potential management. Estudios de Economia Aplicada, 38(4). DOI: https://doi.org/10.25115/eea.v38i4.4026.

Graf, P., Rowland, Z. (2020). Potential of the Small Enterprise Value Assessment Using the Discounted FCFF Method. In Ashmarina S.I., Horák J., Vrbka J., Šulěr P. (eds) Economic Systems in the New Era: Stable Systems in an Unstable World. IES 2020. Lecture Notes in Networks and Systems, 13 November 2020 - 14 November 2020 (vol. 160 , pp. 846-855). https://doi.org/10.1007/978-3-030-60929-0_109.

Khanin, S., Tulchynska, S., Popelo, O., Derhaliuk, M., Ishchejkin, T. (2021). Systematization of functional features of intellectual and innovative determinants of the intensification of the regional economic development. Laplage em Revista (International), 7(2), 710-720. https://doi.org/10.24115/S2446-62202021721118p.710-720.

Kleshchov, A., Terentiev, O., Shevchuk, N., Temchenko, O. (2020). Assessment of the energy efficiency potential of mining enterprises. E3S Web of Conferences, 7 September 2020 - 11 September 2020 (vol. 201, 01034). https://doi.org/10.1051/e3sconf/202020101034.

Korepanov, G., Yatskevych, I., Popova, O., Shevtsiv, L., Marych, M., Purtskhvanidze, O. (2020). Managing the financial stability potential of crisis enterprises. International Journal of Advanced Research in Engineering and Technology, 11(4), 359-371. https://ssrn.com/abstract=3599794.

Krawczyk-Sokolowska, I., Pierscieniak, A., Caputa, W. (2021). The innovation potential of the enterprise in the context of the economy and the business model. Review of Managerial Science, 15(1), 103-124. https://doi.org/10.1007/s11846-019-00374-z.

Popelo, O., Tulchynska, S., Sytnyk, H., Vysochyn, I., Khanin, S. (2021). Formation of imperatives of the creative economy creation under the influence of intellectual and innovative determinants. Laplage em Revista (International), 7(Extra B), 624-633. https://laplageemrevista.editorialaar.com/index.php/lpg1/article/view/1110/1013

Rementsov, A., Lebedeva, N., Kirichenko, O. (2019). Assessment of technological potential of fuel enterprises and their production system. E3S Web of Conferences, 20 November 2019 - 22 November 2019 (vol. 1645, 10039). https://doi.org/10.1051/e3sconf/202016410039.

Samiilenko, H., Popelo, O., Khudolei, V., Mashnenkov, K., Derkachenko, Yu. (2021). Transformational processes of clustering in digital economy. Laplage em Revista (International), 7(Extra C), 691-702. https://doi.org/10.24115/S2446-622020217Extra-C1106p.691 -702

Samoilovych, A., Garafonova, O., Popelo, O., Marhasova, V., \& Lazarenko, Yu. (2021). World experience and ukrainian realities of digital transformation of regions in the context of the information economy development. Financial and credit activity: problems of theory and practice, (3(38)), 316-325. https://doi.org/10.18371/fcaptp.v3i38.237462

Sychev, M., Evstafieva, A., Pozdeev, V., Chugunova, I. (2020). Management of sustainable economic potential of construction enterprise. IOP Conference Series: Materials Science and Engineering, 29 April 2020 - 15 May 2020 (vol. 890, is. 112, 012115). DOI:10.1088/1757-899x/890/1/012115.

Tulchynska, S., Vovk, O., Popelo, O., Saloid, S., Kostiunik, O. (2021). Innovation and investment strategies to intensify the potential modernization and to increase the competitiveness of microeconomic systems. IJCSNS International Journal of Computer Science and Network Security, 21(6), 161-168. https://doi.org/10.22937/IJCSNS.2021.21.6.22. 